\title{
EFFECT OF HIGH FAT AND NUTRIENT DEPLETED DIETS ON COLON TUMOR FORMATION IN MICE
}

\author{
NORMAN J. TEMPLE and SHUKRI M. EL-KHATIB
}

Department of Biochemistry. School of Medicine, Universidad Central del Caribe, Box 995, Cayey, PR 00694 (Puerto Rico)

(Received 17 February 1987)

(Revised version received 11 May 1987)

(Accepted 12 June 1987)

\section{SUMMARY}

We investigated the effect of high fat and nutrient depleted diets on the formation of colon tumors in female Swiss mice treated with 1,2dimethylhydrazine (DMH). Mice received the following diets: control diet (laboratory chow, $5.5 \%$ fat) or chow with added starch and/or corn oil so as to supply a fat level of $5.5 \%$ (diet $F 6$ ) or $23 \%$ (diet F23), while reducing the level of nutrients and dietary fiber per 100 calories to $61 \%$ of the level of the control diet. DMH was given as 5 weekly s.c. injections. Diets were given variously from 6 weeks before the first injection until 7 days after the last one (initiation period) or else for the subsequent 22 weeks until sacrifice of the mice (promotion period). A high fat diet (diet F23 vs. F6) tended to increase adenoma formation when fed during the initiation period but this requires further study. Feeding it in the promotion period increased the incidence of adenocarcinomas. A nutrient depleted diet (diet F6 vs. the control diet) caused a decreased incidence of adenocarcinomas.

\section{INTRODUCTION}

Numerous investigators have studied the effect of dietary fat on carcinogen induced colon tumor formation in rats, and occasionally mice. The large majority of experiments have indicated that fat increases tumor yield $[9,10]$. But contradictory findings have appeared. Thus in two separate studies from the same group, rats fed a high fat diet had, either the same [4] or a slightly reduced yield of colon tumors [6]. The explanation for these discordant results is unclear.

Address for reprints: Dr. S. El Khatib. 
The stage at which dietary fat affects colon carcinogenesis has been subject to very little attention. Each of the following reports concerns azoxymethane treated rats. Reddy and colleagues $[7,10]$ reported that dietary fat was a promoter (i.e. it increased tumor yield when fed after the carcinogen). However, in these studies the possible influence of dietary fat on tumor initiation was not tested (i.e. whether dietary fat was effective when fed at the time of carcinogen administration). Subsequently, Reddy and Maruyama [8] and Bull et al. [2] reported that beef fat exerted an enhancing effect on promotion but not on initiation. Thus dietary fat appears to act mainly or entirely at the promotion stage.

In the present study we have further investigated whether dietary fat affects colon carcinogenesis. This was tested in DMH treated Swiss mice at both the initiation and promotion periods. We also examined whether a nutrient depleted diet affects colon tumor response. This tests the possibility that the relatively large quantities of refined carbohydrates consumed in the modern Western diet (which cause an appreciable drop in the intake of fiber and nutrients) alter colon cancer susceptibility.

\section{MATERIALS AND METHODS}

\section{Mice and treatment}

Swiss Webster mice were purchased from Camm Research, Wayne, New Jersey and were bred locally. At an age of 6-9 weeks female mice were placed on the experimental diets (mean wt. $27.6 \pm 5.5 \mathrm{~g} \pm$ S.D.). They were housed in a temperature-controlled room with a 12-h light-dark cycle.

After 6 weeks on the experimental diets the mice were given the first of 5 week s.c. injections of DMH (Sigma Chemical Co., St. Louis, MO). This was dissolved in $1 \mathrm{mM}$ EDTA and neutralized with saturated sodium bicarbonate. The first dose was $19 \mathrm{mg} \mathrm{DMH} \cdot \mathrm{diHCl} / \mathrm{kg}$ body wt. followed by doses $24,29,26$ and then $45 \mathrm{mg} / \mathrm{kg}$. The use of a gradually rising dose is based on the observation that mice develop tolerance to $\mathrm{DMH}$ and thus allows the number of injections to be reduced while minimizing toxic effects [13].

\section{Diets}

Diet formulation is shown in Table 1. Fresh food was given ad libitum every 1-2 days (usually daily). Where indicated, diets were changed 7 days after the last injection. Dietary treatments were given from 6 weeks before the first DMH injection until 7 days after the last injection (initiation period) or for the following 22 weeks until sacrifice of mice (promotion period).

\section{Tumor assessment}

Twenty-seven weeks after the first DMH injection, mice were sacrificed and internal organs grossly examined. The colon (including the cecum) was opened and carefully examined. Suspect tumors were removed and placed in 
TABLE 1

COMPOSITION OF DIETS

In each case water was added to the diet $(0.8-0.9 \mathrm{I} / \mathrm{kg}$. Composition is expressed on a dry weight basis. Diets were prepared every $2-3$ days and stored at $5^{\circ} \mathrm{C}$.

\begin{tabular}{|c|c|c|c|}
\hline \multirow{2}{*}{ Ingredients } & \multicolumn{3}{|c|}{ Diet, $\%$ composition by weight } \\
\hline & Control & F6 & F23 \\
\hline $\begin{array}{l}\text { Chow } \\
\text { Corn oil } \\
\text { Oleic acid } \\
\text { Starch }^{\mathrm{b}}\end{array}$ & 100 & $\begin{array}{l}67 \\
1.9\end{array}$ & $\begin{array}{l}81 \\
18.5 \\
0.28\end{array}$ \\
\hline $\begin{array}{l}\text { Fat content } \\
\text { Nutrient/calories }\end{array}$ & $100^{5.5}$ & $\begin{array}{l}5.5 \\
61\end{array}$ & $\begin{array}{l}23 \\
61\end{array}$ \\
\hline
\end{tabular}

The chow was rodent laboratory chow meal (Ralston Purina Co., St. Louis, MO) for the first 10 weeks. After that R-M-H 3200 meal was used (Agway Inc., Syracuse, NY). Both consist mainly of cereal and vegetable foods and contain approximately $23 \%$ protein, $5.5 \%$ fat, $14 \%$ neutral detergent fiber, and an adequate concentration of all nutrients. Physiological energy is 3300 $\mathrm{kcal} / \mathrm{kg}$.

'Wheat starch from United States Biochemical Corp., Cleveland, Ohio.

Relative content of vitamins, minerals, protein, and fiber/100 calories.

neutral buffered formulin. They were confirmed after staining ( $H \& E)[5,12]$. Data were analyzed by two-tailed Student's $t$-test and by Chi-square.

\section{RESULTS AND DISCUSSION}

Colon tumors were largely $(75 \%)$ found between 0.5 and $4.5 \mathrm{~cm}$ from the anus (i.e. in the distal colon). The remainder were almost entirely in the midcolon. In addition, two mice had lung tumors and one an adenocarcinoma of the pancreas and duodenum.

By making multiple comparisons, both with and without pooling of different groups, dietary effects on colon tumor formation can be assessed. This can be done separately for the initiation and promotion periods.

Feeding a high fat diet during the initiation period showed no consistent effect (i.e. diets F23 vs. F6). With two of the comparisons (Groups 3 vs. $1 ; 4$ vs. 2) there was no particular trend but with the third (groups 8 vs. 7) mice fed a high fat diet had a significantly higher incidence of colon tumors, both total $(P<0.025)$ and adenomas $(P<0.05)$. On balance, therefore, dietary fat might have an enhancing effect during initiation but this requires further study. When fed during the promotion period, a high fat diet caused a clear rise in the incidence of adenocarcinomas (groups 2 vs. $1 ; 4$ vs. 3 ; significant after pooling, $P<0.05$ ). These findings therefore support earlier observations that dietary fat has a strong promoting action on chemically induced colon cancer $[2,8]$. 
TABLE 2

EFFECT OF HIGH FAT AND NUTRIENT DEPLETED DIETS ON THE INCIDENCE AND TYPE OF COLON TUMORS IN MICE TREATED WITH DMH

\begin{tabular}{|c|c|c|c|c|c|c|c|c|c|}
\hline \multirow[t]{2}{*}{ Group } & \multicolumn{2}{|c|}{ Dieury treatment ${ }^{2}$} & \multirow{2}{*}{$\begin{array}{l}\text { No. of } \\
\text { mice }\end{array}$} & \multicolumn{2}{|c|}{$\begin{array}{l}\text { \%of mice with eolon } \\
\text { tumors (tumor incidence) }\end{array}$} & \multirow[b]{2}{*}{ Adenocarcinoma } & \multicolumn{2}{|c|}{$\begin{array}{l}\text { Colon tumors/tumor besring mouse } \\
\text { (tumor multiplicity) }\end{array}$} & \multirow[b]{2}{*}{ Adenocureinoma } \\
\hline & $\begin{array}{l}\text { Initistion } \\
\text { period }\end{array}$ & $\begin{array}{l}\text { Promotion } \\
\text { period }\end{array}$ & & Total & Adenoma & & Total & Adenom: & \\
\hline 1 & ro & FG & 19 & 26.3 & 26.3 & $53^{\mathrm{B}}$ & $1.60 \pm 0.89$ & $120 \pm 0.45$ & $0.40 \pm 0.89$ \\
\hline 2 & $\mathrm{Fr}$ & F23 & 17 & 41.2 & 17.6 & $29.1^{B}$ & $1.43 \pm 0.79$ & $0.71 \pm 0.95$ & $0.71 \pm 0.49$ \\
\hline 3 & r23 & FB & 20 & 20.0 & 15.0 & $5.0^{8}$ & $1,00 \pm 0.00^{h}$ & $0.75 \pm 0.50$ & $0.25 \pm 0.50$ \\
\hline 4 & $\mathrm{~F} 2 \mathrm{~s}$ & F23 & 19 & 36.8 & 26.3 & $15.8^{8}$ & $1.71 \pm 0.95$ & $1.29 \pm 1.25$ & $0.43 \pm 0.53$ \\
\hline 5 & Control & Control & 18 & $38.9^{\mathrm{d}}$ & 16.7 & 27.8 & $1.29=0.76$ & $0.57 \pm 0.79$ & $0.71 \pm 0.49$ \\
\hline B & Control & FB & 18 & 27.8 & 22.2 & 5.6 & $1.40 \pm 0.89$ & $120 \pm 1.10$ & $0.20 \pm 0.45$ \\
\hline 7 & F6 & Control & 22 & $4,5^{d, 0}$ & $4.5^{?}$ & 4.5 & 2.00 & 1.00 & 1.00 \\
\hline 8 & $\mathrm{~F} 23$ & Control & 15 & $40.0^{\circ}$ & $33.3^{f}$ & 20.0 & $2.83 \pm 1.47^{\mathrm{h}}$ & $1.67 \pm 1.37$ & $1.17 \pm 1.60$ \\
\hline
\end{tabular}

The indicated dietary treatments were given from 6 weeks before the first DMH injection until 7 days after the last injection (initiation period) or lor the following 22 weeks until sacriffee of the mice (promotion period).

b Only a limited number of statistical comparisons were made, anmely those indiested in Results and Discusslor. Figures sharing the same suffix are significantly different.

CMean \pm S.D.

d.e Sigalficantly dilferent by Fisher's test, $P<0.025$.

Sigrificantly dilferent by Fisher's teat, $P<0.05$.

Groups 2 and 4 pooled vs. 1 and 3 pooled, significantly dilferent by Fisher's test. $P<0.05$

hSigaificantly dilterent by Student's t-test, $P<0.05$. 
The major feature of feeding a nutrient depleted diet (F6), as compared to the control diet, is a decreased incidence of adenocarcinomas. This was seen in 3 out of 5 comparisons (groups 7 vs. $5 ; 6$ vs. 5 and 3 vs. 8 but not 1 vs. 6 or 1 vs. 7). This observation is surprising since the nutrient depleted diet has only $61 \%$ of the content of nutrients and dietary fibre per 100 calories as compared to the control diet. Apparently, this serious loss of nutrients has not adversely affected the body's defenses against cancer.

Furthermore, diet $\mathrm{F} 6$ increases the fecal $\mathrm{pH}$ [14], a change which should supposedly enhance not protect against colon carcinogenesis $[3,15]$. Possibly the fibre content of the control diet (lab chow) is excessive or it contains harmful xenobiotics. It is significant that we previously observed that feeding a nutrient depleted diet (compared with the control diet) increases the mortality rate in the days following an injection of DMH [13]. This suggests an altered susceptibility to the acute effects (and therefore initiating action?) of DMH.

\section{ACKNOWLEDGEMENTS}

The authors thank Mrs. Myrna Nieves for skillful technical assistance, Mrs. Mabel Baaske and Mrs. Sandra Gasovan for histological work and Dr. Lawrence Jewell (Department of Pathology, University Hospital, Edmonton, Canada) for advice on the interpretation of colon tumors. We also thank The Alberta Heritage Foundation for Medical Research for financial support.

\section{REFERENCES}

1 Bansal, B.R., Rhoads, J.E. and Bansal, S.C. (1978) Effect of diet on colon carcinogenesis and the immune system in rats treated with 1,2-dimethylhydrazine. Cancer Res., 38, 3293-3303.

2. Bull, A.W., Soullier, B.K., Wilson, P.S., Hayden, M.T. and Nigro, N.D. (1979) Promotion of azoxymethane-induced cancer by high-fat diet in rats. Cancer Res., 39, 4956-4959.

3 Jacobs, L.R. and Lupton, J.R. (1982) Dietary wheat bran lowers colonic pH in rats. J. Nutr., $112,592-594$.

4 Locniskar, M., Nauss, K.M., Kaufmann, P. and Newberne, P.M. (1985) Interaction of dietary fat and route of carcinogen administration on 1,2-dimethylhydrazine-induced colon tumorigenesis in rats. Carcinogenesis, 6, 349-354.

5 Madara, J.L., Harte, P., Deasy, J., Ross, D., Lahey, S. and Steele, G. (1983) Evidence for an adenoma-carcinoma sequence in dimethylhydrazine-induced neoplasms of rat intestinal epithelium. Am. J. Pathol, 110, 230-235.

6 Nauss, K.M., Locniskar, M. and Newberne, P.M. (1983) Effect of alterations in the quality and quantity of dietary fat on 1,2-dimethylhydrazine-induced colon tumorigenesis in rats. Cancer. Res., 43, 4083-4090.

7 Reddy, B.S. and Maeura, Y. (1984) Tumor promotion by dietary fat in azoxymethane-induced colon carcinogenesis in female F344 rats: influence of amount and source of dietary fat. J. Natl. Cancer Inst., 72.

8 Reddy, B.S. and Maruyana, H. (1986) Effect of different levels of dietary corn oil and lard during the initiation phase of colon carcinogenesis in F344 rats. J. Natl. Cancer Inst., 77, $815-822$.

9 Reddy, B.S., Narisawa, T. and Weisburger, J.H. (1976) Effect of diet with high levels of protein and fat on colon carcinogenesis in F344 rats treated with 1,2-dimethylhydrazine. J. Natl. Cancer Inst., 57, 567-569. 
10 Reddy, B.S., Watanabe, K. and Weisburger, J.H. (1977) Effect of high fat diet on colon carcinogenesis in F344 rats treated with 1,2-dimethylhydrazine, methylazoxymethanol acetate, or methylnitrosourea. Cancer Res., 37, 4156-4159.

11 Reddy, B.S. Tanaka, T. and Simi, B. (1985) Effect of different levels of dietary trans fat or corn oil on azoxymethane-induced colon carcinogenesis in F344 rats. J. Natl. Cancer Inst., 75, 791-798.

12 Robbins, S.H., Cotran, R.S. and Kumar, V. (1984) Pathologic basis of disease, pp. 218-220. Saunders, New York.

13 Temple, N.J. and El-Khatib, S.M. (1985) Toxicity of 1,2-dimethylhydrazine in mice: effect of diet and development of tolerance. J. Food Safety, 7, 77-81.

14 Temple N.J. and El-Khatib, S.M. (1987) High-fat and nutrient depleted diets and the enzyme profile of feces and colon mucosa of mice. J. Nutr. Growth Cancer, 4, 38.1-38.7.

15 Thornton, J.R. (1981) High colonic pH promotes colorectal cancer. Lancet, 1, 1081 - 1083. 